\title{
Modernizing Reforms and Turkish Music in the 1930s
}

\section{Orhan Tekelioğlu}

To cite this article: Orhan Tekelioğlu (2001) Modernizing Reforms and Turkish Music in the 1930s, Turkish Studies, 2:1, 93-108, DOI: 10.1080/14683849.2001.11009175

To link to this article: https://doi.org/10.1080/14683849.2001.11009175

$$
\text { 曲 Published online: } 03 \text { Nov } 2014 .
$$

Submit your article to this journal $₫$

Џll Article views: 239

Citing articles: 9 View citing articles 5 


\title{
Modernizing Reforms and Turkish Music in the 1930s
}

\author{
ORHAN TEKELIOĞLU
}

\begin{abstract}
The Turkish Republic's policy on music during the 1930s is explored in the events leading to the closure of a unique yet short-lived music magazine Nota which published 37 issues in the 1930s. The founding years of Turkey were characterized by reforms in the cultural sphere including music as part of a modernizing and Westernizing strategy. These reforms were, however, challenged by a handful of skilled musicians as well as by the audience's traditional Ottoman music.
\end{abstract}

The founding years of the Turkish Republic were marked by a series of fundamental changes within the cultural sphere. Referred to as "revolutions" (devrimler or inkllaplar in the plural) by the young republic's ruling elite, the changes were designed to bring about the transformation of social structures along the lines of a developing, but as yet immature, notion of "national identity." These were top-down reforms originating from within the state itself. One of the most striking and iconoclastic cultural reforms replaced the Arabic with the Latin alphabet in written Turkish.

Other reforms also had a deep impact on the everyday life of the masses. They included the adoption of the European hat, the Western calendar, and a new system of weights to conform to international standards. The reforms that had perhaps the greatest impact on the people were those to do with religion. In 1926, the Sharia, the formal Islamic code of law, was replaced by a secular Western civil code. Parallel measures against folk Islam had already been taken with the abolition of the religious lodges and cloisters (tekke ve zaviyeler) in 1925, suspending the practices of the Dervish orders.

The culmination of all these reforms was in 1929 with the introduction of the National Schools, intended to instill the new nationalistic and proWestern identity. The curriculum was designed to teach the new Latin script, principles of secularism, and cultural values introduced in those reforms for the next generations. The reforms were implemented quite 
rapidly and the literacy level rose from around 8 percent in 1928 to over 20 percent in 1935. In addition to National Schools, the People's Houses (Halkevleri) provided free education to adults.

\section{Reforms in Turkish Music}

The reform of Turkish music during the republic's early years and into the 1940 s is a little-known but very interesting case of the direction and implementation of these changes. Reforms in music can be first detected in the idea of the "imposed synthesis," developed by the young republic's leading ideologue, Ziya Gökalp.'

Gökalp's well-known book, Principles of Turkism (1923), provided the ideological foundations for the new republic and to a certain extent was a manual for implementing "the fusion" of Turkish ideas "with those of the West." Gökalp considered the eventual success of the new nation-state and Turkish nationalism to be closely connected with the development of a new "Turkish Civilization." He spoke of how Turkish music could become national and outlined a program for its future development.

Gökalp divided existing music in the main Turkish lands into three classes: Eastern, Western, and folk. He argued that the music of the elite during the pre-Republican era, although the peak of Ottoman cultural achievement in terms of music, was essentially Byzantine which he called "Eastern." To reinforce his point, he referred to ancient Greek music which, because it was based on quarter tones and tended to repeat "the same melody over and over," he found "artificial" and "depressingly monotonous." However, claimed Gökalp, musical reforms during the Middle Ages in Europe had gone far to overcome the mistakes of Greek music, with opera going even further and giving rise to the "civilized" Western music known today.

On the other hand, the Eastern music that emerged from ancient Greek models and had been played for centuries in the Ottoman lands continued in its "ill" state. He concluded that the only "healthy" music in Anatolia was folk music, enjoyed by the Turkish people as a whole. Only if "our national culture" welds with "our new civilization" (the West), emphasized Gökalp, can one speak of a "national music."

In other words, to create a new national music for the Turks, Ottoman (Eastern) music was to be discarded; folk music was to be the primary source; and musical reform was to be based on Western music and its 
harmony. Folk tunes were to be collected, categorized, reworked according to Western methods, and made polyphonic. The model of synthesis for both Gökalp and Mustafa Kemal was similar experiences in Russia, where a group of composers known as "The Russian Five" had followed such a path to achieve a "national synthesis" in music during the nineteenth century. ${ }^{2}$

The policy directed toward establishing a new form of music based on a synthesis between East and West began to bear fruit in 1924, one year after the foundation of the Turkish Republic. The Palace Symphony Orchestra (Saray Senfoni Orkestrast), the only musical institution performing polyphonic music in the Ottoman era, was abolished in April. The new orchestra set up in its place was named the Presidential Music Band (Riyaseti Cumhur Orkestrast). In addition, the orchestra's training institute, the Palace Military Band (Saray Mızlkası), another vestige from the Ottoman period and comprised of the musicians educated in the Palace Military Band School (Saray Mızıka Mektebi), was closed down and reopened in September of the same year under the name "School for Music Trainers" (Musiki Muallimleri Mektebi). In 1926, the Oriental Music Section (Sark Musikisi Subesi), the only public educational institution with a curriculum similar to that of Western conservatories, was closed down. ${ }^{3}$ A complete ban was put on monophonic music education (that is Ottoman-originated Turkish music) in public and private schools in 1927.

The enactment of the law abolishing religious lodges and cloisters in 1926 dealt a serious blow to the music used during the performance of religious rituals called "tekke," which became practically extinct. This left many talented tekke musicians without a livelihood. After the 1930s, in Istanbul and other cities, some of them began to secularize their music and commercialize their work to earn a living. They created a new genre in popular music whose "Eastern" roots, made it a major obstacle to the republican elite's efforts to create a "West-East" synthesis."

Musical reform issues were discussed and brought before the public through very fierce debates in newspapers, especially in 1927. Prominent pro-government columnists severely attacked the "Eastern" elements of Turkish society derived from the obsolete Ottoman system.

In 1928, Mustafa Kemal made his first public assessment of Turkish music. He attended a concert where two groups-one performing Turkish music and the other "Western"-played in succession. His response was that 
this unsophisticated music, cannot feed the needs of the innovative Turkish soul, the Turkish sensibility in all its urge to explore new paths. We have just heard music of the civilized world, and the people, who gave a rather anemic reaction to the murmurings known as Eastern music, immediately came to life....Turks are, indeed, naturally vivacious and high-spirited, and if these admirable characteristics were for a time not perceived, it was not their fault. ${ }^{3}$

Mustafa Kemal blamed Ottoman intellectuals for their lack of awareness of the Turkish "character" and accused them of coercing Turks into listening to soporific music that ran contrary to their spirit.

\section{Cultural Policies in the Field of Music}

From the beginning of the late 1930s, the state implemented a number of coordinated cultural policies in the field of music:

1. Formal education in Western polyphonic music began in conservatories modeled on Western schools. Foreign experts and instructors were hired while some gifted students were sent abroad for training.

2. Symphony orchestras began giving free concerts around the country. Both serious and popular works of Western polyphonic music were regularly broadcast on radio.

3. Courses in music were offered to the public free of charge in the People's Houses where both polyphonic music and standardized monophonic folk tunes were played.

4. At "State Balls,"-music and dance nights organized by government employees in cities-examples of Western dance music were selected from among light pieces such as waltzes and tangos.

5. In schools, however, there was little in the way of teaching the actual playing of instruments. A rather extensive coverage of Western musical history and its composers was put into the curriculum.

Most Turkish music listeners, however, showed little interest in either the polyphonic music being composed by the Turkish composers or the Western classical music played in free concerts or broadcast on radio. Instead, people of the large urban centers began to enjoy popular songs 
composed and played by former tekke musicians or listened to Arab radio stations broadcasting Arab music. ${ }^{6}$ The cultural elite had failed to develop any harmonic form of popular music accepted by a broad segment of the people.

\section{A Music Magazine in the Wake of Cultural Policies}

At the height of this cultural revolution, the first issue of Nota was published on April 5, 1930. According to its first editorial, it would specialize in publishing the scores of popular contemporary tunes. The magazine's editor, Mildan Niyazi Ayomak (1887-1947), was a music educator and a composer of the Ottoman Classical Music genre. Ayomak had been a political activist during the Ottoman period and had been exiled in Egypt, then under Ottoman control, where he was exposed to Arab and Middle Eastern motifs and taste in music. After his many years in exile, he moved back to İzmir and in 1920 founded the Izmir Musiki Mektebi (Music School of Izmir).

Owing to the ban placed on Turkish music education in 1927, his school lost its raison d'être and had to completely revise its curriculum to focus on other subjects. It reopened as the School of Life Knowledge (Hayat Bilgisi Mektebi) and continued, with less success, its program in adult education until 1932. After closing the school, Mildan Niyazi moved to Istanbul, where he founded the Istanbul Musiki Birligi (Music Association of Istanbul), for professional musicians coming from the Ottoman music genre. One of the association's projects was Nota. After Nota closed down in November 1934, the association also dissolved in 1935.

It is undoubtedly possible to attribute the magazine's short life span to poor sales figures or the editor's personal needs, but more likely Nota was closed for political reasons.

\section{Nota's Idea of Synthesis}

The first issue established its position in the daily debates on musical reforms. It is clear from Nota's motto that the magazine had its own idea of synthesis: "While defending our personality, gradually toward the New Music." This idea of "gradual development" in new music was, in fact, a riposte to the revolutionary idea of sudden change adopted by the cultural elite. In the first editorial, entitled "Why we publish?" Niyazi defined the 
situation of music in Turkey during the 1930s accurately. He described the economic and social conditions of musicians and composers of the Ottoman classical music tradition, most of them from the tekke tradition:

What has become the fundamental aim of daily music is not mastery but rather profit. Because of the shortage of learned musicians, worthless tunes are appreciated and sold throughout the country, thereby reducing the level of music....We should thoroughly determine the route through which our music can rise again.... Alaturka [Ottoman Classical Music] music cannot be transformed into alafranga [Western] music. This is because their essentials and sounds are totally different. We cannot simply adopt Western music as it is because we would not be able to call it our music. We should preserve and accept the music that we have already, in its own context and with its own instruments (nay and tanbur).... In order to create our own international music, we should work on our own melodies... and then polyphonize them [according to the rules of Western harmonic music]. This is indeed the greatest ideal of our magazine.?

This approach challenges Ziya Gökalp's idea which considers Anatolian folk tunes as the main source of an East-West synthesis. The notion of "our own music" is instead to be fulfilled by adapting the tunes of urban Ottoman music rather than on those of a "fictive" folk music of the countryside. The term "fictive" is deliberately chosen, because the folk music of Anatolia virtually did not exist in the Ottoman urban centers. The literate musicians and composers of the day had learned, practiced, and performed music in an urban setting. This is perhaps why the magazine praised Eastern musicconsidered by Gökalp as a sign of backwardness-as "our own music."

In any case, the editorial is bitter in tone and is representative of the general attitude the magazine took toward the state of affairs confronting Ottoman-style musicians in the 1930s. It is easy to comprehend the enormous difficulties facing these musicians. In a similar vein, the following excerpt from the news article entitled "We have also lost Kaptanzade," about the death of a famous composer in the genre of Ottoman music, is also illuminating:

In the February 20 issue of Cumhuriyet [an influential, progovernment daily], on one of the back pages, it was reported under 
the headline, "Karagöz Lover's Society," that the chairman of the society, the composer Kaptanzade Ali Riza Bey, had passed away while on a visit to Balıkesir [a small city close to Istanbul] to perform in concerts. The report also listed the possible candidates for the post of chairman. That is to say, we would not have known about this sad event if the society had not existed or if the deceased had not been its chairman. We should never forget that we once learned from a short and awkward sentence written in one of the newspapers, about the death of Tanburi Tahsin Bey [a well-known player of the tanbur].... Poor musicians of this country! They work, they wear themselves out...and eventually, without disturbing anyone else's life, without hurting anyone, say farewell. Ironically, the only 'reward' they receive, whether dead or alive, is a bare expression of grief from an insensitive milieu."

Thus, the official media and its culture ignore the classical alaturka musicians from the Ottoman tradition who were once musical heroes. Over time, and especially after its 11 th issue, Nota became more defensive and less critical of official policies, perhaps due to the pressures it was receiving from those who supported the government's policy. A defensive editorial about the musical reforms heading, written personally by Mildan Niyazi in 1933, is interesting in this regard:

[We] cannot imagine anyone who could reject a need for clearance, reform and revolution in our music.... We think that only with these [reforms], can our music take off its şalvar [baggy trousers of the people in countryside in the Ottoman age] and fes [a popular form of hat from the Ottoman era], and put on its [Western] trousers and hat."'

Niyazi understood he was compelled to change his tone from defending Ottoman music to emphasizing the "backwardness" of the Ottoman era and Western culture's superiority. By the 25 th issue, the editor was admitting the cultural elite's "discontent" with his views:

We know very well that our magazine has been unable to satisfy the readers involved in Western music. Yet, the basis of our interest in both types of music in equal degree is a natural outcome of our music profession. As we wrote in the editorial of our first issue... we 
are very happy to even dream of polyphonic Turkish music reaching the international arena. In our opinion, this [can happen] only... when talented minds know Eastern and Western music equally, well, and because of this belief, we publish examples of both genres in equal size. And, with the same belief, we try hard to elaborate simple and discrete rules for Turkish music, especially for people involved in Western music so that they can quickly understand the rules and theories of Turkish music which otherwise would be impossible for them to comprehend in years, let alone months. ${ }^{10}$

This signaled a retreat from making Ottoman music the national music to a proposal for equality between the two genres. The editor somewhat misrepresents his original stance since the first editorial had insisted that the already existing music should be preserved as it was composed, with its sounds and instruments intact.

\section{Content of the Magazine}

In addition, the editor had not accurately represented the magazine's actual contents. While Nota favored an East-West synthesis, its emphasis was not on serious music in a Western polyphonic form for the elite listener, but rather popular monophonic tunes, mostly in song format, for the ordinary listener. Such monophonic compositions published in Nota were different from Ottoman popular songs more in their words than in their music.

The lyrics are now mostly secular, narrating a new lifestyle for the less religious listener living in an urban setting. While forerunners of this approach can be sensed in some of the lyrics of late Ottoman classical music, nevertheless, almost all the scores of popular songs published in Nota have this orientation. These songs very much reflected the new realities of the republican and secular Turkey's new urban lifestyle. In some tunes, male and female choirs sang refrains comprised of flirtatious complaints about the opposite sex. Another interesting example of this secular attitude could be found in the song entitled Prozit Şarkısı [Song for Cheers], specifically composed for drinking houses and inspired by the German style of toast when drinking with someone.

There were, however, also some differences in the music itself. Traditional Turkish music is based on certain fixed modal structures 
(makam) written at the beginning of the score. In the new compositions, strange and previously unheard hybrid modal structures began to appear forged in the spirit of the "East-West synthesis". One of the most striking examples was a new makam called Nihavent-Tango, based on the traditional structure of the Nihavent modality, rhythmically fused with the Western tango. In a similar vein, another new modal structure, the Oryantal-Fokstrot (Oriental-Foxtrot) was invented." A third example of such blends was the Sultan-ı Yegâh, based on a traditional yegâh makam. Originally imperial in manner (thus the reason behind its name "Sultan's Yegâh"), upon being "nationalized," it was retitled Milli Yegâh, which means "Nation's Yegâh." This new name for the traditional makam was used in the scores published by Nota and continued to be popular until the 1950s.

In addition to the new scores of popular tunes, the magazine also presented biographies of popular contemporary composers and singers. It is striking that the overwhelming majority of new popular musicians had tekke origins, either directly or through their teachers.

In the latter category, Nota praised one of the rising stars of the day, Münir Nurettin Selçuk (1900-81), now considered the last great singer/performer of the Ottoman classical musical genre in the Republican era. Brought up in the tekke tradition, too, was the most praised composer/performer, Sadettin Kaynak (1895-1961), who was a cantor (hafiz) of the Koran. ${ }^{12}$ An established star of the period, Kaynak not only collaborated with Münir Nurettin but also, in later years, was responsible for the adaptation of songs from Arab films. Through his understanding of composition, he was able to produce not a "synthesis" but rather a "modernization" of classical Ottoman music which succeeded in changing the musical taste of Turkish listeners. The comment on Kaynak in Nota gave an early and realistic evaluation of what would become the standard in Turkish popular music and "taste" in the years to come:

Certainly, and with great success, [Sadettin] himself has invented a way of music that portrays in song the genuine existence of the Turk, perhaps long before the Ottomans. This way includes the flavors found in our folk music, yet [at the same time] is definitively different from it.... In these compositions...one may single out a color corresponding to the taste of the day. It is our fervent desire and hope that compositions of this type become the basis for our musical harmonics. ${ }^{13}$ 
Here again is an indirect attack launched against the cultural elite and "folk music" idea of Ziya Gökalp. It is Kaynak's work, influenced by Ottoman music, which is truly connected to the "genuine existence of the Turk." In his style of composition, Nota's idea of proper Turkish music would ultimately triumph.

\section{A Questionnaire on the Future of Turkish Music}

In the first issue of its second year, Nota published an open letter in which the ongoing intense debate over Eastern and Western music was summarized and a public appeal was made to musicians of both genres to present their views about a possible future East-West synthesis in Turkish music. To structure the responses, a very detailed questionnaire was prepared. ${ }^{14}$ The responses, which began to be published in subsequent issues, revealed that there was nearly unanimous support for Western, polyphonic music, endorsing official cultural policies. Strangely, there were no replies from either pro-monophonic readers or the editor, though most of these letters had been written in a rather insulting tone. This strange "silence" can only be explained as a form of self-censorship by the majority of Nota readers. At the same time, the extent of the pro-Western responses demonstrated the degree to which Nota had keen and critical readers and observers from among the pro-Western cultural elite.

The following response to the questionnaire can be considered typical and serve as a basis of understanding how the "official" view on the topic was formulated. The letter is signed by llyas Bey, chief representative of the Fine Arts Branch of the People's House of Trabzon. It is known that in the foundation years of the Republic, People's Houses were the main sites for disseminating the cultural policies of the state to the public. Ilyas Bey, moved by the "revolutionary" spirit, openly attacked the existing monophonic music as weak and not suitable for the masses:

The monophonic music that has been practiced so far, ... including its [popular] song forms being composed at the present moment, is undoubtedly very feeble compared to the music being composed for the masses. The Turkey of 1934 and its new and intellectual generations cannot be satisfied with this tekke-smelling music; [the masses] demand a more expressive, lively and energetic form of music. In order to realize this, our classical music should be 
reworked with the classical techniques of Western music so as to achieve a richness of expression and description that will eventually develop into concert and stage music. In addition to that, essentials of an energetic culture of music, equal to that of the Western jazz music, should be constructed. ${ }^{15}$

The idea of how true music must be composed is then clearly formulated. First and foremost, music is for the masses and thus must be "expressive, lively and energetic." Since music is for the masses, it should also have the emphasis and quality of concert or stage music. Illyas Bey continues his assessment of the structure of Turkish music and makes a very peculiar suggestion:

Modal structures [makams] which are not so different from one another and make our music vague and difficult to comprehend, should also be reworked and reduced to one single essential form. Either one of the modal structures such as Uşak, Hûseyni, Muhayyer, Karciğer, which are in essence not so different from one another, should be chosen or a new modal structure covering all the components of the cited modalities should be created. Concerning this, the new modalities should be based on and classified according to the Western major and minor scales and their specifications.

Therefore, according to him, all the structural developments that had taken place in Ottoman classical music should be changed immediately and made to resemble those based on the minor and major scales of Western music. This view was that the only developed and "true" music was undoubtedly Western music, with its major and minor scales.

Two issues later, there came the elitist critique of Ercüment Behzat Lav (1903-83), a well-known poet, theater and cultural figure, who was working as a senior radio announcer. This critique was significant not only because Lav was a prominent public figure, but also because he held a senior post in the state-owned radio, which was to place a ban on Turkish music in November of the same year. It is also important to note that Lav would become the director of radio programs in 1935, just months after his assessment of the situation of Turkish music was published in Nota. His promotion is not coincidental, if one reads closely the assessment in which Lav refers directly to the Russian nationalism in music: 
Up until Tchaikovsky, Russian music had been an ordinary blueprint of Central European Music. [Only after] Russian composers worked on the folk songs of the masses did they reach today's maturity. If Brahms had not worked on national motifs, the music of Hungary would not have appeared in the repertoire of the world's orchestras... The nucleus of tomorrow's Turkish music lies to a great extent in the Anatolian tunes of today.... What our millions require is neither mystical tekke music, nor mey [wine], nor muğbeçe [server in drinking house], nor bade [wine-glass], nor yar [beloved]...Without delay, we must give our people, now living like a spent wave, sonic food on a universal scale. The damage already done to people's minds by drinking-house songs and musically worthless jazz tunes is comparable to the use of morphine and cocaine. We should not forget that in some countries, where the musical culture is not weak as in our own, jazz is forbidden in order to protect the musical taste of the people. Today, if a person were to try to organize his life along the line of Ömer Hayyam or Mevlana, he would very likely to be considered mad and perhaps even be locked up. It is a social necessity in this mechanizing Turkey of today to confine to the dustbin of history the opium-like music of unlearned man, which is played on the $u d$ [oriental lute] and tef [tambourine]. As the first step in this sorting and cleansing operation for the ear, the publication and printing of records of songs should be strictly limited and controlled. ${ }^{16}$

These critiques suggest that Nota was under siege. In Lav's words the original formula of Ziya Gökalp is repeated and also Anatolian tunes are mentioned as the source for the East-West synthesis in music. In addition, Lav blatantly rejects that there is any other way for synthesis to occur, for instance in popular music, since for him this would be no different from the "drinking-house songs" or "worthless" entertainment music that he groups alongside a socially undesirable "jazz." Lav even speaks of a "cleansing" operation and suggests a total prohibition on publishing scores or making records of such music. If this desire is coupled with the upcoming ban placed on Turkish music in November 1934, it is not difficult to imagine that his next post on the state-controlled radio would be chief director of radio programs.

The ban placed on Turkish music has an exciting history of its own. Mustafa Kemal, in his opening speech at the 1934 session of parliament, 
made his second public assessment of Turkish music. Stressing that advancement in the fine arts must be encouraged without delay, he asked for a rapid program to be made in music, and continued as follows:

The measure of the change undergone by a nation is its capacity to absorb and grasp a change in music. The music that they are trying to get people to listen to today is not our music, so it can hardly fill the bill. We must not lose sight of this fact. What is required is the collection of national expression that conveys fine thoughts and feelings, and without delay putting it to music along the lines of the most modern rules. Only in this way can Turkish national music rise to take its place among the music of the world. ${ }^{17}$

One of the immediate outcomes of this speech was the broadcasting ban placed on Turkish music, ${ }^{18}$ announced November 3, 1934. Even though this ban was lifted after 20 months, it was replaced by a systematic form of censorship that described the type of Turkish music that could be played on the radio and, later, on television. The monopoly of Turkish Radio and Television in broadcasting was not abolished until the early 1990s.

The only positive, yet oblique, response to the questionnaire from the pro-Ottoman music side came from a well-known violinist, Kemani lzzet, who used a very cautious and defensive tone. In his response, he preferred to discuss the real meaning of what is called alaturka, which, according to Izzet, was mostly and imprecisely mixed with what is "Eastern." For Izzet, the alaturka genre, by its very nature, is a very versatile format, and thus suitable for Western harmony:

Alaturka music is perfectly suitable for taking motifs. If we are able to educate scholarly composers of good taste, they may help our music achieve a position wherein it will be praised by international music authorities. Even though the Western system of harmonics is based on major and minor scales, it is not only confined to them; there does exist a full liberty.... One may easily use every motif existing in alaturka music. ${ }^{19}$

Thus in Izzet's eyes, alaturka music is full of motifs that could be combined with both the plain and advanced structures of Western music. It is interesting to note that among the many responses made to the questionnaire in Nota, this was the only one evaluating Turkish alaturka 
music in a somewhat positive way. Izzet's response was the last one to appear in Nota, which suspended the publication of any other responses in forthcoming issues. After its 37 th issue, without prior farewell to its readers, this unique score magazine of the popular songs was abruptly closed down.

\section{Conclusion}

The history of Nota in many ways reflects the dynamics and consequences of the cultural reforms carried out during the foundation years of the Turkish Republic. One of the most noteworthy consequences is that the Republican project of Westernization was executed "from above," in a rather authoritarian way, without giving consideration to any social resistance. To the cultural elite, Nota represented a critical attitude directed toward the already established policies of the young state, which did not tolerate such attitudes. The intellectuals and rulers of the new republic wholeheartedly believed in the existence of universal truths, such as the developed and civilized state of Western music in relation to the backwardness of Turkish music. As a result, they came up with an unmediated, naively positivistic solution: folk tunes were to be harmonized, using the methods of Western music, and made polyphonic.

Another consequence of this particular history of music was the negligence demonstrated by the cultural elite toward positive offers coming from alaturka musicians. While the ruling elite totally rejected the previous Ottoman political institution, they still had to make some strange coalitions with vestiges of the Ottoman political elite. In contrast, on the musical scene, the cultural elite of the young republic not only completely rejected the musical heritage coming from the Ottoman period, but also completely denied the possibility of modernizing Ottoman music, which had, in fact, been to the taste of urban listeners. Instead, they preferred Gökalp's idea of a synthesis of East and West based upon a "fictive" folk music which, during the Ottoman era, had neither existed in urban centers nor been known thoroughly by the prominent musicians of the day. Without any intellectualization, Nota had come up with its own idea of synthesis that was not a rejection but rather an alternative approach to the republican version. However, this brave attempt was not only disregarded by the cultural elite, but suppressed. 
The main reason that the Republican cultural elite rejected the novel idea of synthesis put forth by Nota is more than likely related to their lack of interest in culture, including music. This is particularly discernible if one considers the "from above" character of the Turkish political socialization that tended to cultivate rulers who were insensitive to cultural components coming "from below." This tendency toward insensitivity is widespread in all public discussions of cultural policies. Particularly striking in relation to the notion of East-West synthesis in music is the absence of debate on the possibility of a synthesis in popular music. On the contrary, the young republic and its cadre were more interested in solutions for the masses for the sake of the masses-a political reflex remaining from the state-oriented Ottoman Empire. Consequently, no thought was given to the notion that any form of popular music could be something that most of the people (the so-called "masses") could enjoy or identify with.

In conclusion, it may be argued that the "from above" strategy of the 1930s, inevitably produced its "from below" counter movements and resistance in the years to come. As observed in Nota, musicians as well as listeners resisted with new compositions and by people's listening choices. While they lost the battle in the 1930s, as in the case of the closing down of Nota, they eventually developed their own synthesis in the 1950s, as well as thereafter. It is within these politico-cultural dynamics that the modern popular music of Turkey has been shaped.

\section{NOTES}

1. For the notions of the "spontaneous synthesis" and "imposed synthesis", see Orhan Tekelioglu, "The Rise of a Spontaneous Synthesis: The Historical Background of Turkish Popular Music," Middle Eastern Studies, Vol.32, No.2 (April 1996), pp.194-216.

2. Murat Belge et al., Atatürk Devrimleri Ideolojisinin Türk Mizik Kültürüne Doğrudan ve Dolaylt Etkileri [Direct and Indirect Impact of the Ideology of Atatiork's Reforms on the Turkish Musical Culture] (Istanbul: Boğaziçi Üniversitesi Türk Müziği Kluba Yayınları, 1980), pp.34, 48.

3. Gültekin Oransay, Atatürk ile Küğ [Atatürk and Music] (lzmir: Küg Yayını, 1985), p.112.

4. For the conceptual difference between the "West-East" and "East-West" syntheses, see Tekelioglu, Middle Eastern Studies (April 1996), p.197.

5. Oransay (1985), p.24.

6. Martin Stokes, The Arabesk Debate. Music and Musicians in Modern Turkey (New York: Oxford University Press, 1992), p.93. See also Nazife Güngör, Arabesk. Sosyokillürel Açıdan Arabesk Mizik [Arabesk. A Sociocultural View of Arabesk Music] (Ankara: Bilgi Yayınları, 1990), p.55. 
7. Nota, No.1, April 5, 1933, p.2.

8. Nota, No.22, March 1, 1934, p.101.

9. Nota, No.11, Sept. 15, 1933, p.42.

10. Nota, No.25, April 11, 1934, p.113.

11. It is interesting to note that contrary to Ziya Gökalp's consideration, the Eastern element, namely, makam-based music of Ottoman tradition, is conceived here in a purely positive way in a possible synthesis.

12. Because of his background, he was often called simply ' $\mathrm{Haf}, \mathrm{z}$ ' in the musical milieu.

13. Nota, No.19, Jan. 15, 1934, p.92.

14. Nota, No.25, April 15, 1934, p.120.

15. Nota, No.28, June 1, 1934, p.134.

16. Nota, No.30, July 1, 1934, p. 143.

17. Oransay (1985), p.26.

18. Oransay (1985), p.49.

19. Nota, No.32, Aug. 1, 1934, p.149. 